\title{
シミュレータ映像による身体動摇
}

\section{村井康二*・林 祐司 $*$ 内内藤晴嗣**・井口征士*** \\ A Study on Operator's Body Sway in Visual Simulation of Ship Handling Simulator}

\author{
Koji MURAI, Yuji HAYASHI, Harutsugu NAITOH \\ and Seiji INOKUCHI
}

\begin{abstract}
Ship's Navigator gets diverse information from the ship and her environment for safe and efficient navigation, and visual information is the most important information source. Simulator is used to do some education and training of ship handling, and navigational environment simulate using visual simulator.

We have advanced an analysis of unconscious subjects' body response to visual simulation of the simulator, in case of 210 and 150 degrees' horizontal angles, gravity of body center was led toward a picture by the recognition of visual rolling. However, the subjects were only experienced persons (or navigators), and it is not carried out to do about inexperienced persons.

In this study, we use the moving of gravity that body response was obvious in our index. And, we carried out the experiment to seven subjects (four experienced persons and three inexperienced persons), four kinds of horizontal visual field (210, 150, 90, 30 degrees) and nine kinds of inclination of rolling (from 0.0 to 20.1 degrees). We show characteristics of the subjects who are the persons easy to get seasick, experienced persons and inexperienced persons.
\end{abstract}

\section{1.はじめに}

操船者は、安全な航海を実現するために視覚から の情報を主に用いて、船舶周辺の航海環境から多く の航海情報を獲得していると考えられる。そして著 者らは、今日頻繁に活用されている操船シミュレー 夕(以下、シミュレータと呼ぶ。) の模擬する航海環 境である映像が無意識レベルで操船者に与える身体 的、生理的影響に注目し、水平視野角（210度、150 度、90度)の大き別に、映像により模擬したRolling に対する身体応答についての解析を、重心動摇、鼻 部皮膚温、 $\mathrm{R}-\mathrm{R}$ 間隔等の生理指標を用いることで進 めてきた(1)-(3)。

その結果、水平視野角が広視野の場合、視覚的な
船体横傾斜の認識により、身体重心は映像の傾斜方 向に誘導され、その特徵量は重心動摇の変化に対し て顕著であることが明らかになった。しかし、前回 の実験では、被験者が乗船経験者（以下、経験者と 呼ぶ。）のみであり、乗船未経験者（以下、未経験者 と呼ぶ。）についての検討、比較は行われていない。 経験者、未経験者別にそれぞれ身体応答の差異が定 量的に評洒できる可能性が見出せれば、経験により 培われる感性(4)-(7) を無意識レベルの身体応答から 定量的、客観的に評価できる可能性があると考之ら れる。また、船舶に対する身体動摇の解析は船酔い、 乗り心地および船体運動に対する人体応答を対象と した研究(8)-(12) が行われているが、シミュレータ映 像に対する身体動摇に関する研究は見られない。

* 正 会 員 神戸商船大学商船学部（干658-0022 神戸市東灘区深江南町5-1-1）

**学生会員 神戸商船大学大学院（T658-0022 神戸市東灘区深江南町5-1-1）

***非 会 員 大阪大学大学院基礎工学研究科（T560-8531 豊中市待兼山町1-3） 
本研究では、著者らが用いてきた指標の中で、身 体応答の特徵量が顕著であった重心動摇に注目す る。そして、4種類の水平視野角 (210度、150度、90 度、30度)、9段階の船体横傾斜に対する船体横摇れ 模擬実験を7名の被験者に対して前報(3)の実験装置 および手順で行い、重心動摇の解析を行う。そして、 経験者、未経験者および船醉いしやすい被験者に対 して得られた特徵について報告する。

\section{2.シミュレータ映像による船体横摇れ 実験 $^{(3)}$}

実験は、神戸商船大学レーダ航法実験研究装置棟 内のシミュレータを用いて行った。被験者は経験者 4名、未経験者3名の合計7名である。被験者の乗船経 験年数、性別等を表 1 に示す。なお、被験者C、Eは「船 酔いしやすい」と自己申告している。

船体横摇れの模擬はシミュレー夕映像により行 い、波高（0から 8 メートルの 1 メートル間隔）に より 9 段階の横摇れ (Rolling) を発生させる。被験 者は、シミュレータのスクリーン曲面の中心位置 (映 像計算基準位置）に置いた平衡機能測定装置の検查 架台の上に船首方向に正対して立つ。そして、各波 高に対して本船を真針路000度で航走させ、真方位 090度から横波を受けるように状況設定されたシ ミュレータ映像を 3 分間注視し、続く1分間閉眼して 休息する。そして、休息中に船体動摇の程度を「動 摇を感じない：0 人「動摇を感じる：0.5～5」の11段 階の主観値を用いて評価し、報告する。また、各水 平視野角に対する一連の実験終了後には、さらに各 波高の実験に対するシミュレータ映像への印象や、 吐き気、汗ばみ等の詳細な主観評洒をアンケート用 紙により回答する。シミュレー夕映像は、海域掞よ び雲量0の空域のみとし、陸域や物標等は表示しな

表 1 実験対象者

\begin{tabular}{cccccccc} 
& $\mathrm{A}$ & $\mathrm{B}$ & $\mathrm{C}$ & $\mathrm{D}$ & $\mathrm{E}$ & $\mathrm{F}$ & $\mathrm{G}$ \\
\hline 性別 & 男 & 男 & 男 & 男 & 男 & 男 & 男 \\
年领 & 48 & 23 & 21 & 21 & 19 & 19 & 19 \\
経験年数(年) & 10 & 1 & 0.25 & 0.25 & 0 & 0 & 0
\end{tabular}

表 2 設定波高と周波数、波長、最大船体横傾斜角 の関係

\begin{tabular}{|c|r|r|r|r|r|r|c|c|}
\hline 波高[m] & \multicolumn{1}{|c|}{1} & \multicolumn{1}{c|}{2} & \multicolumn{1}{c|}{3} & \multicolumn{1}{c|}{4} & \multicolumn{1}{c|}{5} & \multicolumn{1}{c|}{6} & \multicolumn{1}{c|}{7} & \multicolumn{1}{c|}{8} \\
\hline 周波数[Hz] & 0.294 & 0.204 & 0.167 & 0.145 & 0.130 & 0.119 & 0.110 & 0.103 \\
\hline 波長[m] & 18.5 & 37.0 & 55.5 & 74.0 & 92.5 & 111.0 & 129.5 & 148.0 \\
\hline 双大船体横傾斜角[deg] & 0.1 & 0.8 & 3.2 & 6.1 & 7.8 & 11.0 & 16.9 & 20.1 \\
\hline
\end{tabular}

い。また、眼高は 8 メートルで一定とする。各設定 波高に対子る周波数、波長、最大船体横傾斜角を表 2 に示す。

\section{3. 身体動摇の解析}

シミュレータの分野ではVR (Virtual Reality)や VE（Virtual Environment）に関係して映像が身体 動摇に与える影響に関する研究(13)-(16)が行われてお り、身体動摇に関する研究は広い分野で解析、評価 が行われている。そして、これら諸研究の重心動摇 に対する従来の解析手法は軌跡長、標準偏差や誘導 角等を指標とし、被験者の全体的な傾向に注目した 研究が多いと考之られる。しかしながら、著者らは 経験者、未経験者の個人の特性を評価することを目 的としていることから、個人が各指標值に対しても つ幅を規準化することにより、各被験者の特徵量を 比較する必要がある。そこで、本研究では動摇幅比、 横傾斜感度、正接角による偏りを指標として提案し 解析を行う。さらに、重心動摇の周波数特性抢よび 主観值と総軌跡長の相関を求兴。

重心動摇の計測は、平衡機能測定装置により被験 者の身体前後方向（以下、身体y方向と呼ぶ。）㧤上 び左右方向（以下、身体 $\mathrm{x}$ 方向と呼ぶ。）の重心位置 データを 0.1 秒間隔でサンプリングし、計算機に収録 する。以下に本研究で用いた解析方法を示す。なお、 本研究でのサンプリング周期は、通常、身体の重心 動摇が周波数によって、 $2 \mathrm{~Hz}$ 程度の比較的高周波な 動きと、0.2 0.3Hz程度の低周波の動きに分けられ ると言われている(17)ことから、高周波成分である 2 Hz辺りまでの範囲を十分に識別できる0.1秒間隔と した。

(1) 重心動摇幅比

各波高別実験中の被験者の重心位置変動幅を身体 動摇幅と定義し、身体x方向㧍よび身体y方向につい て、最大・最小值の差として算出する。そして、波高 0メートルの身体動摇幅に対する比により重心動摇 幅比として求める。この值を用いて、重心動摇の大 きさを評価する。

(2) 横傾斜感度 ${ }^{(1)}$

(1) 式で示すとおり、各波高別実験中に重心位置が 移動した総軌跡長を最大船体横傾斜角で除し、その 值を横傾斜感度と定義する。船体横傾斜が生じた場 合に対する横傾斜角1度あたりの重心動摇の忘答性 を評価する。この横傾斜感度值が大きいほど横傾斜 に対する身体応答の感度が高いとする。 


$$
\text { 横傾斜感度 }=\frac{\text { 総軌跡長 }}{\text { 最大船体横傾斜角 }}
$$

総軌跡長（L）は、0.1秒毎に重心位置が移動した 距離を3分間積分した值で、（2）式により求める。

$$
L=\sum_{i=0}^{1800} \sqrt{\left(x_{i+1}-x_{i}\right)^{2}+\left(y_{i+1}-y_{i}\right)^{2}}
$$

ここで、 $\mathrm{x}_{\mathrm{i}}$ は身体 $\mathrm{x}$ 方向の重心位置デー夕、 $\mathrm{y}_{\mathrm{i}}$ は身体 y方向の重心位置デー夕を示す。

(3) 偏り (r)

被験者の重心動摇の身体x方向および身体y方向 の標準偏差を計算し、その比 $\left(\sigma_{\mathrm{y}} / \sigma_{\mathrm{x}}\right)$ の正接角 [deg] を求める（(3) 式)。この值から、重心動摇方向の偏 りの程度を評価する。

$$
r=\tan ^{-1}\left(\frac{\sigma_{\mathrm{y}}}{\sigma_{\mathrm{x}}}\right)
$$

偏りrの值と重心動摇方向の関係は次のようにな る。

- $r<45$ ：身体x方向に長軸をもつ楕円形。

- $r=45$ : 円形。

・ $r>45$ ：身体y方向に長軸をもつ楕円形。

(4) 周波数解析

身体x方向および身体y方向の周波数成分を FFT により計算する。そして、シミュレータ映像の船体 横傾斜により誘導された被験者の重心動摇のピーク 周波数を求める。この值から、船体横傾斜と重心動 摇の周期性の関係を検討する。

(5) 主観值

主観値は、シミュレー夕映像の船体横傾斜に対す る動摇感(1)(3)について、動摇を感じないが「0」、動摇 を感じるが「0.5」から「5」までの数值として、0.5 単位のレベルを設定し、全11段階の評価を被験者自 らが行う。本研究では波高を 0 〜 8 メトルの 9 段 階変化させており、各波高に対して映像から受ける 主観評価を9段階以上のレベルで判別可能とするた めに、5 段階評価にさらに 0.5 単位のレベル設定を 行っている。

\section{4. 結果と考察}

4 種類の水平視野角、9段階の船体横傾斜に対する 重心動摇について、前節の指標を用いた解析結果を 示す。

\section{1 重心動摇の測定結果}

重心動摇の測定結果の一例として、乗船経験年数 が最も長い被験者Aの場合を図 1 に示す。困 1 は、シ ミュレータ映像を視覚刺激として受ける 3 分間の身 体x方向および身体y方向の重心動摇時系列デ一夕
を各身体力向の平均值を 0 として水平視野角別、波高 0、4、8メートルの場合についてそれぞれ示して いる。

図 1より、水平視野角が広視野（210度、150度） で波高が 4 メートル、8メートルと高く船体横傾斜 が大きくなると身体x方向へ周期的な重心動摇が生 起していることがわかる。しかし、この周期的な重 心動摇は水平視野角が90度の場合、視覚刺激を受け はじめた30秒程度にしか見られず、水平視野角が30 度の場合では見られない。各実験条件に対する重心 動摇は、動摇の「大きさ」とシミュレー夕映像によ る船体横傾斜に誘導される重心動摇の「周期性」に 特徴が見られると考えることができる。

\section{2 重心動摇幅比}

重心動摇の大きさについて、重心動摇がもつとも 顕著な水平視野角 210 度の重心動摇幅比の結果を図 2 に示す。重心動摇の幅は、個人によりばらつきが あるため波高 0 メートルの動摇幅を、個人の開眼時に 拈ける身体基本保持能力の大きさとして規格化して いる。ここで、本論文での身体基本保持能力とは、 開眼時、視覚刺激として傾斜が無くかつ自然体の状 態における重心動摇の大きさとする。

図 2 より、身体方向の重心動摇幅比について、経 験者は未経験者と比べ大きく、波高0メートルのとき と比べ4〜7倍の重心動摇が見られる。また、経験者 は船体横傾斜角約6 11度で最大值をもつ特徵が見 られる。この原因について、経験者は身体動摇幅比 の最大值をもつ船体横傾斜角以降では、Rollingのみ
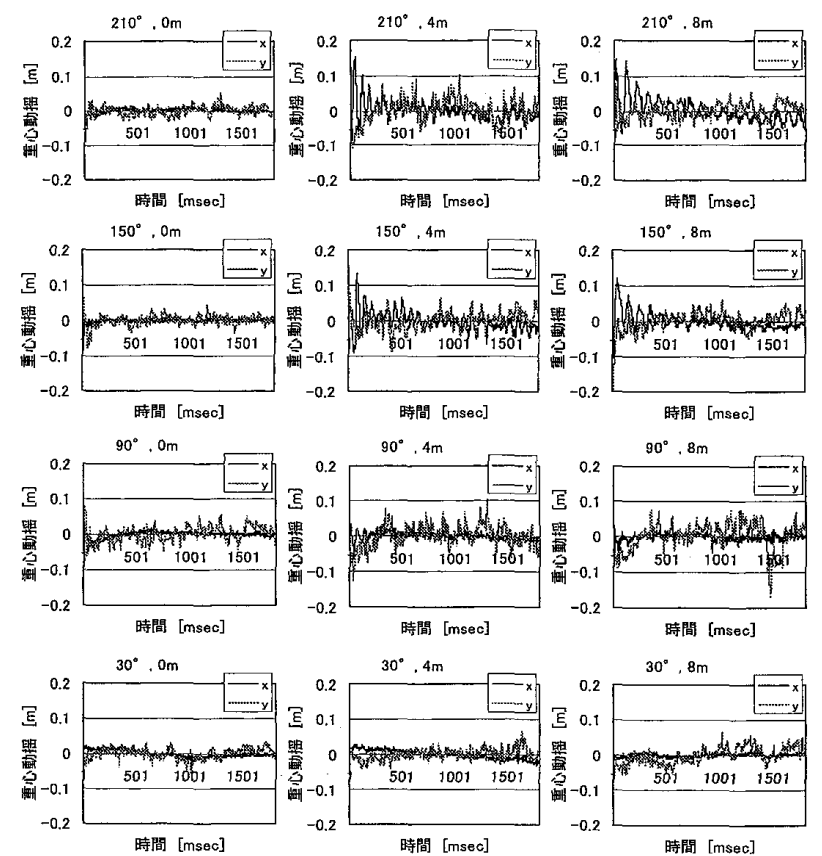

図 1 重心動摇の測定結果 （被験者A、波高 $0 、 4 、 8$ メトル） 

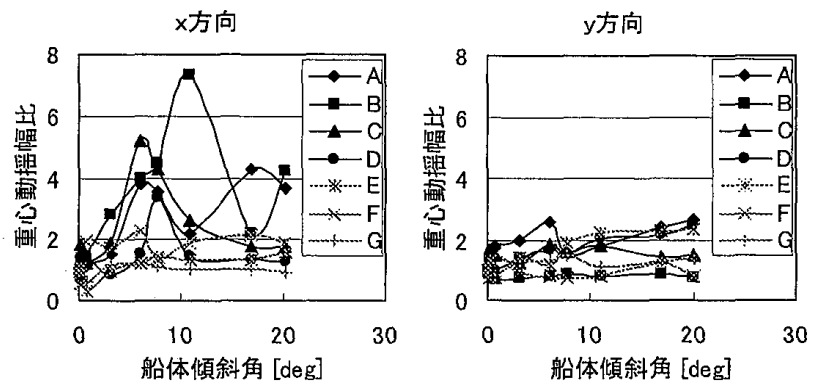

図 2 船体傾斜角と重心動摇幅比の関係 (水平視野角210度)

の船体運動に対して「違和感がある」と主観評価し ており、視覚刺激の影響を受けて重心動摇は生起す るが、その動摇幅は船体横傾斜角の大きさに比例し て增加することは無く、結果として身体応答である 重心動摇は抑制されたと考える。一方、未経験者に はこのような特徵は見られない。また、身体方向の 重心動摇について、全被験者とも重心動摇幅比は3倍 以内に収まっている。これらの結果より、重心動摇 の特徵には経験者と未経験者の間に差異が見られ、 その差異を定量的に評価できる可能性がある。

\section{3 横傾斜感度}

個人により重心動摇のばらつきに幅があること は、個人の身体基本保持能力が異なるために起こる と考之られる。次に、横傾斜に対する感度能力の特 性を見るために、前報 ${ }^{(1)} て ゙$ 提案した指標である横傾 斜感度により経験者、未経験者、船酔いしやすい者 の横傾斜角 1 度あたりに対する重心動摇の応答特性 について得られた結果を図 3 に示す。

図 3 より、船醉いしやすいと自己申告していた被 験者Eを除いて、横傾斜感度の全体的な特性は類似 して扔り、4 種類の水平視野角に対して $\mathrm{y}=\mathrm{a} \times \mathrm{x}^{\mathrm{b}}$ で 近似される。各水平視野角毎に、被験者 6 名の平均 值を用いた近似式の各係数值と $\mathrm{R}^{2}$ 誤差を表 3 に示 す。ここで、 $\mathrm{R}^{2}$ 誤差とは全体の分散に対する近似値 の分散の割合を誤差率として 1 から引いた值であ ク、近似曲線のデー夕に対する当てはまりの度合い を表した決定係数 ( $\mathrm{R}^{2}$ 值)である。この值が1に近づ くほど近似曲線の適合はよい。また、各船体傾斜角 に対する横傾斜感度の值は、被験者 $\mathrm{E}$ 除く被験者6 名の平均值に注目寸ると、水平視野角が大きくなる ほど横傾斜感度の值は大きくなる。被験者Eについ ては、全ての横傾斜角に対して横傾斜感度が他の被 験者のそれより卓越しており、水平視野角 210 度、150 度では波高 5 メートルでピークをもち、他の被験者 とは全く異なる特性を示す。主観評価からピークを もつ波高で、吐き気等の気分の悪化を申告しており
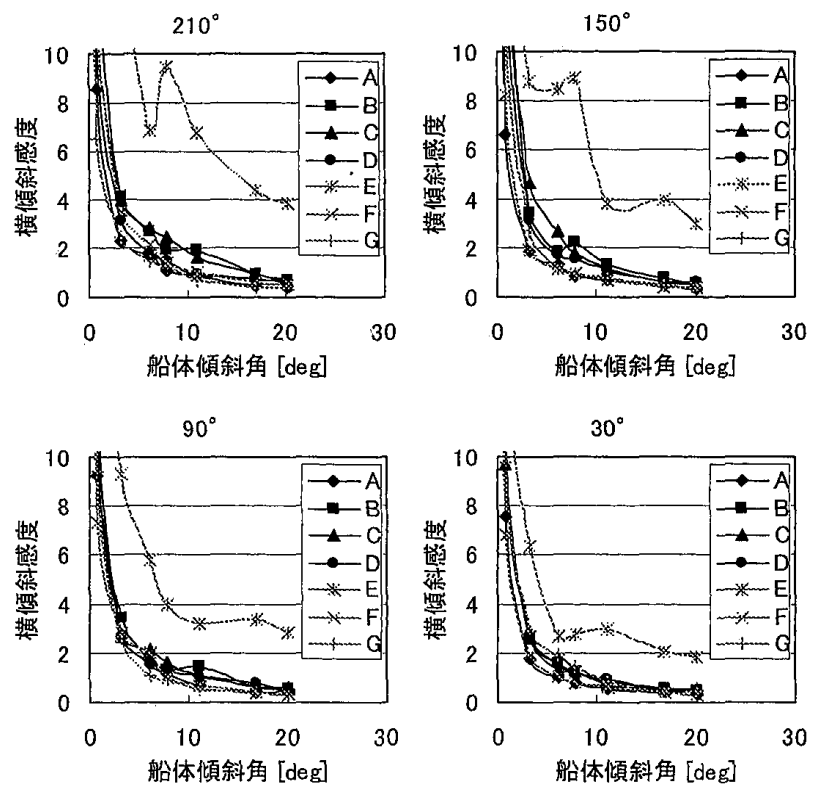

図 3 船体傾斜角 と横傾斜感度の関係

表 3 近似式の各係数値と $\mathrm{R}^{2}$ 誤差

\begin{tabular}{|c|c|c|c|}
\hline 水平視野角 & $\mathrm{a}$ & $\mathrm{b}$ & $\mathrm{R}^{2}$ 誤差 \\
\hline $210^{\circ}$ & 9.59 & -0.91 & 0.99 \\
\hline $150^{\circ}$ & 9.68 & -0.99 & 0.99 \\
\hline $90^{\circ}$ & 8.46 & -0.95 & 0.99 \\
\hline $30^{\circ}$ & 7.68 & -0.98 & 0.99 \\
\hline
\end{tabular}
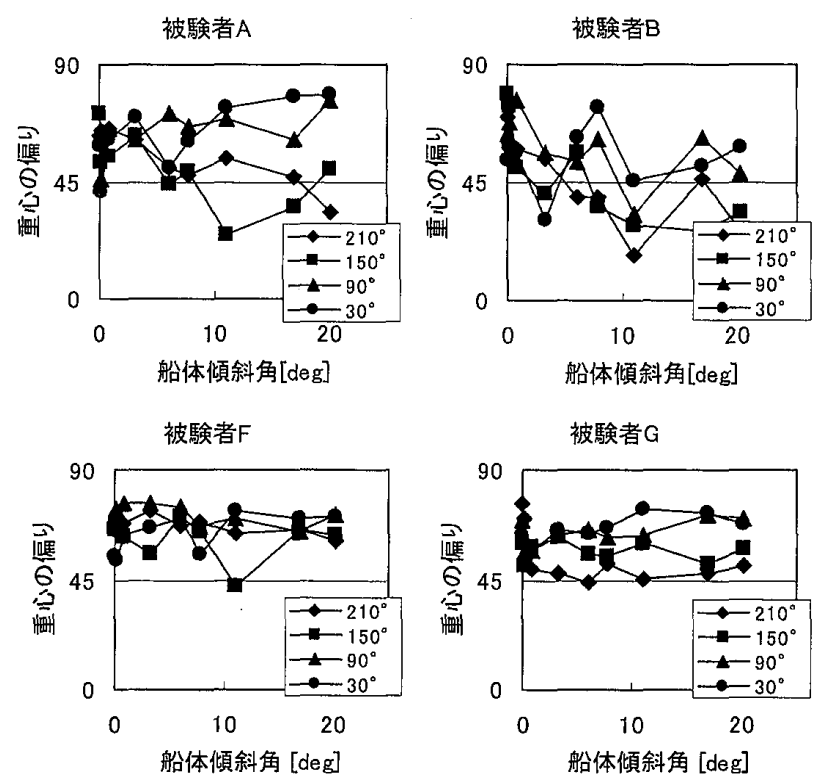

図 4 船体傾斜角と重心動摇の偏りの関係

(被験者 $A 、 B 、 F 、 G)$

顔色も悪く嘔吐をこらえる状態であった。

\section{4 偏り}

重心動摇の偏りについて、経験者 $(\mathrm{A} 、 \mathrm{~B})$ および 未経験者 $(F 、 G)$ の結果を困4に示す。 

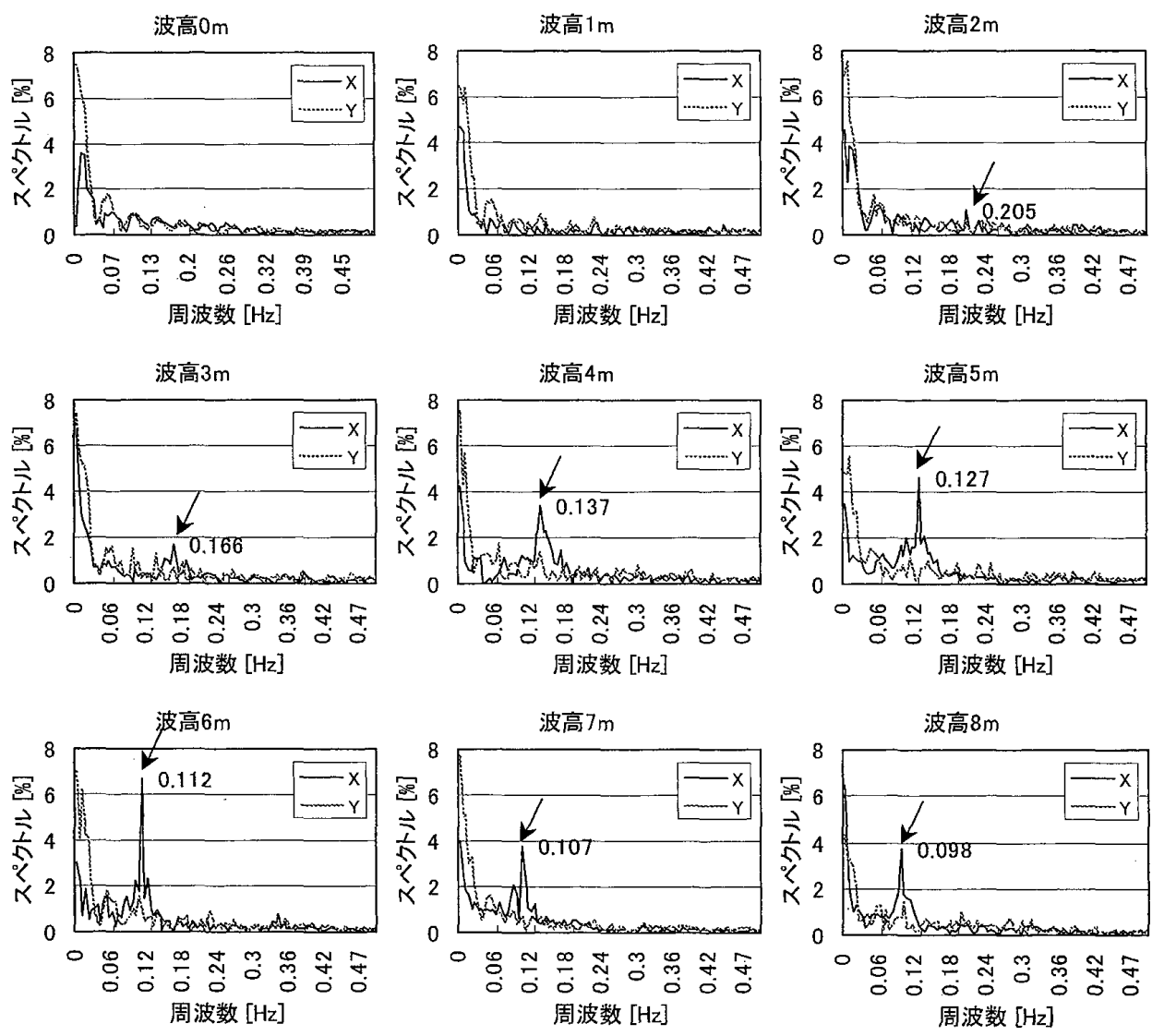

困 $5 \mathrm{a}$ 重心動摇の周波数解析（被験者A、水平視野角210度）

図 4 より、経験者は水平視野角 210 度および150度 において船体傾斜が大きくなると身体方向に偏っ た重心動摇を行う。この傾向は前報 ${ }^{(3)}$ の評価からも 得られており、さらにそれらの結果に対する裹付け ができたと考える。しかし、未経験者は、円形（偏 り值：45）程度にまでしか船体傾斜方向への誘導を 受けていない。換言すれば、未経験者は経験者ほど シミュレータ映像による船体横傾斜に対して、身体 y方向の動摇の大きさに比べ身体x力向に誘導され ないと言える。

4.2節と同様に経験による意識的な違和感が重心 動摇に影響を与えたように、船橋から見る船体運動 の経験の有無が、船体傾斜方向に生じる自己運動感 覚の生起度合いに何らかの影響を与えている可能性 があると考えられる。

\section{5 周波数解析}

4.1節の測定結果から、水平視野角 210 度および150 度に扔いて船体傾斜角が大きくなると身体方向の 重心動摇に周期性が見られる。この周期性について、 FFTにより周波数解析をおこなった結果を経験者

(A)、未経験者 $(\mathrm{F})$ およU゙船酔いしやすい被験者 $\mathrm{E}$ 水平視野角 210 度の場合について図 5 aから図 5 cにそれぞれ示子。図 $5 a-5 c の$ スペクトルは全周波
数成分に対する各周波数成分の割合（\%) で示して いる。

四 5 aより、波高が2メートルから船体横傾斜を 制御するための各波高がもつ周波数周辺に重心動摇 の周波数成分が現われることがわかる。図中に矢印 および周波数を示す。この結果から、シミュレータ 映像による船体横傾斜により誘導される重心動摇 は、船体横傾斜に同調する傾向があることがわかる。 また、波高 0 メートルの場合には身体方向および 身体y方向の周波数成分は類似しており、一定の動 摇で身体の直立を維持していることがわかる。そし て傾斜が起こるとこの特徵は見られなくなる。これ らの傾向は、図 $5 \mathrm{~b}$ 、図 $5 \mathrm{c}$ も見られ経験者、未経 験者、船酔いしやすい等に関係なく全被験者につい て見られる。

\section{6 主観值}

各波高に対する船体横傾斜のシミュレー夕映像か ら得た視覚的な動摇感に対する主観值の結果を被験 者A、Fについて図 6 に示す。

区 6 より、被験者 $\mathrm{A}$ は被験者 $\mathrm{F}$ と比べ水平視野角の 大きさに対して、主観值の差が明確であることがわ かる。そして、この傾向は経験者と未経験者の特徽 として見られる。 

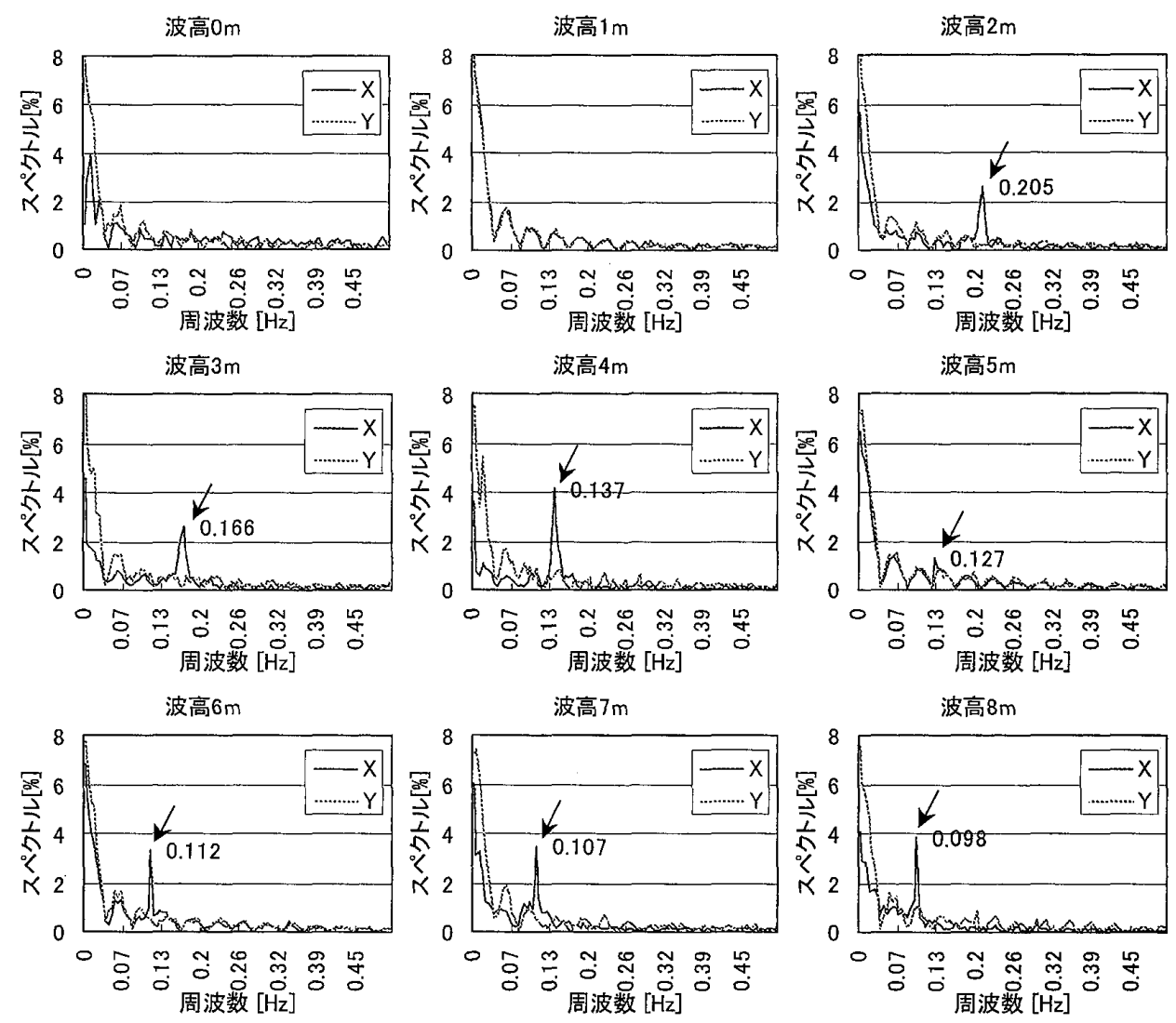

図 $5 \mathrm{~b}$ 重心動摇の周波数解析（被験者 $\mathrm{F} 、$ 水平視野角210度）
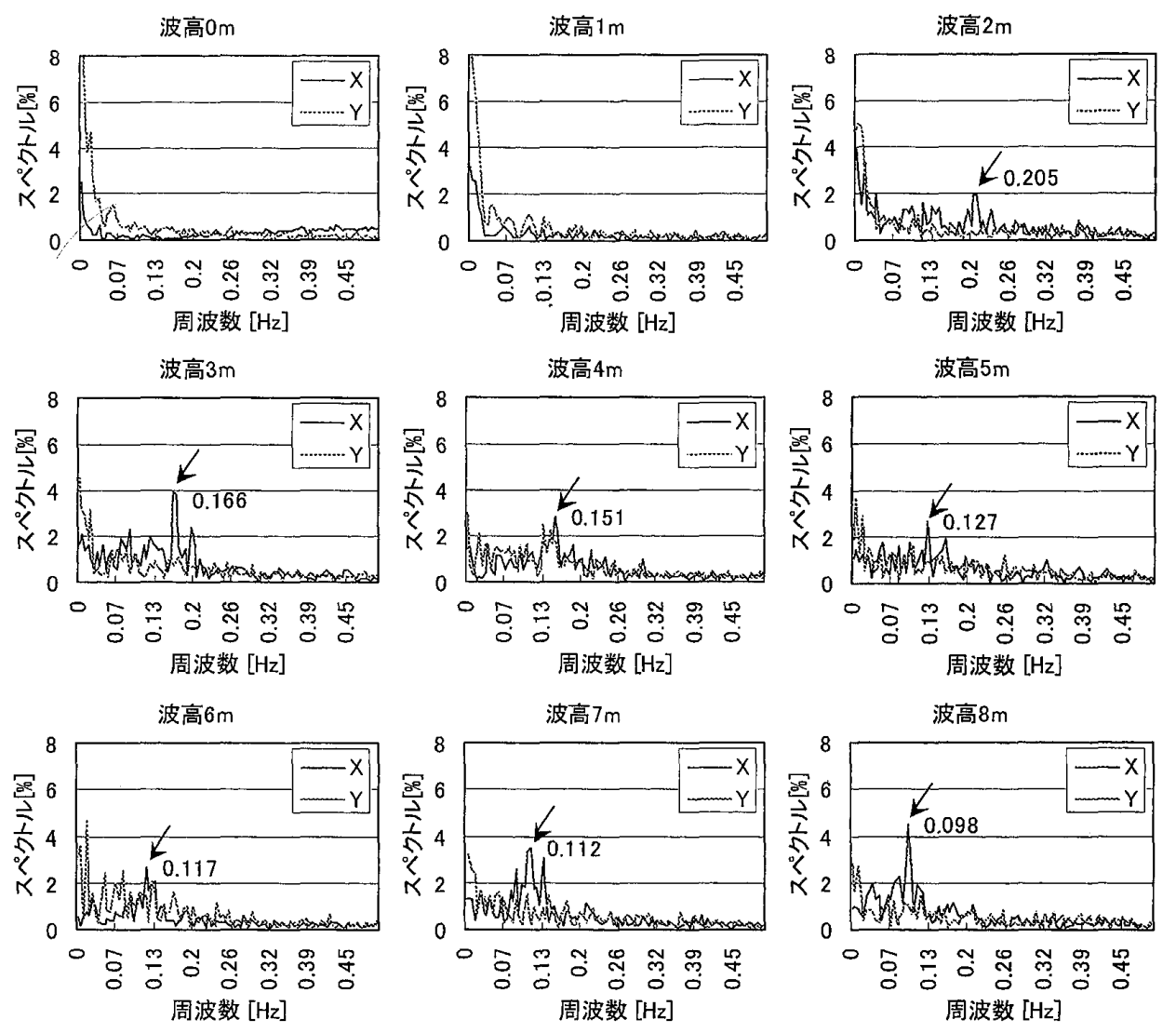

図 $5 \mathrm{c}$ 重心動摇の周波数解析（被験者 $\mathrm{E} 、$ 水平視野角 210 度） 

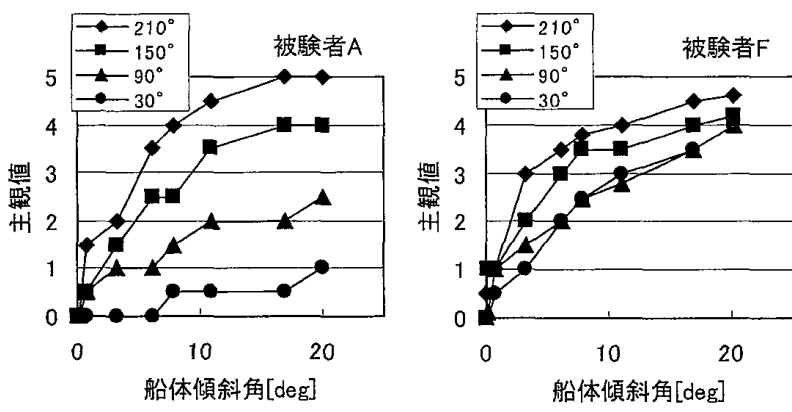

図 6 船体傾斜角々主観值の関係（被験者A，F）

表 4 主観值と総軌跡長の相関係数

\begin{tabular}{|c|c|c|c|c|c|c|c|}
\hline 水平視影角 & $\mathrm{A}$ & $\mathrm{B}$ & $\mathrm{C}$ & $\mathrm{D}$ & $\mathrm{E}$ & $\mathrm{F}$ & $\mathrm{G}$ \\
\hline $210^{\circ}$ & 0.76 & 0.82 & 0.77 & 0.80 & 0.97 & 0.86 & 0.73 \\
\hline $150^{\circ}$ & 0.72 & 0.67 & -0.01 & 0.23 & 0.95 & 0.85 & -0.58 \\
\hline $90^{\circ}$ & 0.40 & 0.82 & 0.39 & 0.94 & 0.92 & 0.24 & -0.48 \\
\hline $30^{\circ}$ & -0.17 & 0.78 & 0.69 & 0.76 & 0.96 & 0.59 & 0.08 \\
\hline
\end{tabular}

次に、主観と身体応答の相関を見るために、主観 值と総軌跡長の相関係数を求めた結果を表 4 に示 す。

表 4 より、水平視野角210度に対して、全被験者に 正の相関がある。また、船酔いしやすい被験者Eにつ いては全ての水平視野角に対して強い正の相関が見 られる。この結果から、顕著な身体応答に対する主 観評価は、客観的評洒としての妥当性を得ることが できる可能性があると考えられる。

\section{5.まとめ}

本論文は、シミュレー夕映像による 9 段階の船体 横傾斜が、視覚から取り込まれた時の無意識レベル の身体応答として、重心動摇がどのように起こるか についての解析・検討を、4 種類 (210度、150度、 90度、30度）の水平視野角に対して行った。そして 以下のことが明らかになった。

・重心動摇は、水平視野角が個人の視野角を覆うよ うな広視野の場合、映像の傾斜方向に誘導される。 そして、その誘導による傾斜方向への偏りは経験 者の方が未経験者より顕著である。

・誘導された重心動摇は、船体動摇周波数と同調し た周波数成分をもつ。

・経験者は、重心動摇幅に顕著な最大值をもつが未 経験者はもたない。

・横傾斜感度の特徵は、船酔いしやすい被験者を除 いて同傾向を示す。

- 水平視野角 210 度の場合、全被験者に対して主観值 と重心動摇の総軌跡長に正の相関がある。

本研究によって、シミュレー夕映像による船体横
傾斜が、経験者および未経験者の重心動摇に与之る 影響を定量的、客観的に評価できたと考える。また、 シミュレータ映像によっても無意識レベルで重心動 摇が生起し、その個人への影響は、船酔いしやすい 者にとっては 3 分間で哣吐症状の前兆が得られるほ どであり、教育訓練に用いられる各種シミュレータ のビジュアル効果を軽視できない。今後は、この身 体応答、主観評価を十分に支持できる生理指標とそ の評価方法の確立を進めて行きたい。

\section{謝辞}

本研究を進めるにあたり実験に協力していただい た神戸商船大学河口信義助教授、若林伸和助教授、 井川晶裕技官、桑原和洋氏および神户商船大学航海 学研究室、大阪大学基礎工学部瀬井裕子氏に厚くお 礼申し上げます。

\section{参 考 文 献}

(1) 村井康二・三好雄一：シミュレー夕による視覚 と身体応答の関係に関する基礎研究，日本航海 学会論文集，103号，pp. 167-173 (2000).

(2) Koji Murai and Yuji Hayashi : Occurred Seasick Impression and Analysis of the Observer's Heart Rate Variability by using Ship's Bridge Simulator, Proceedings of 2001 ICASE International Conference on Control, Automation and Systems, pp. 1291-1295 (2001).

(3) 村井康二・林 祐司 - 瀬井裕子 - 井口征士：操 船シミュレー夕の水平視野角と現実感の関係 一重心動摇と鼻部皮膚温の計測-, 日本航海学会 墖文集，106号，pp. 131-138（2002）。

（4）井口征士 他5名：感性情報処理, pp. 1-12, 103-130，才一ム社.

（5）行場次朗・箱田裕司：知性と感性の心理, pp. 60-75, 福村出版.

（6）八木昭宏：感性の物理計測，日本ファジ学会 誌, Vol. 9, No. 3, pp. 318-326 (1997).

(7) 元木紀雄 - 矢野澄男 : 3次元画像と人間の科学, 8章, オーム社.

(8) 花田力：動摇病の実態に関する研究, 目耳鼻, Vol. 69, No. 5, pp. 46-74 (1966).

（9）後藤大三：人体応答よりみた振動限界, 日本造 船学会誌, No. 583, pp. 10-21 (1978).

(10) 木村暢夫 ·川島利兵衛：船体運動と人体の応答 に関する基礎研究-I，日本航海学会論文集，69 
号，pp. 67-75 (1983).

（11）木村暢夫・川島利兵衛：船体運動と人体の応答 に関する基礎研究-III，日本航海学会論文集， 71 号, pp. 63-70 (1984).

（12）川崎潤二 ·天下井清 - 木村啺夫 - 甫喜本司：船 体運動に対する人間の応答特性，日本航海学会 論文集，87号，pp. 79-88（1992）。

（13）畑田豊彦・坂田晴夫・日下秀夫：画面サイズに よる方问感覚誘導効果, テレビジョン学会誌, Vol. 33, No. 5, pp. 407-413 (1979).

(14) 清水俊宏 - 矢野澄男：広視野視覚刺激と聴覚刺 激の同期提示による重心動摇への誘導効果，電 子情報通信学会論文誌, Vol. J83-A, No. 7, pp. 912-919 (2000).

（15）竹田仰・金子照之：広視野映像が重心動摇に及 ぼす影響，テレビジョン学会誌，Vol. 50, No. 12, pp. 1935-1940 (1996).

(16) 元木紀雄 - 矢野澄男：3 次元画像と人間の科 学, 6 章, オ一公社.

(17) De Wit, G. : The stabilometry as an auxiliary in investigations of patients with vestibular disturbances, Agressologie, 14, pp. 27-31 (1973)

\section{質 疑 応 答}

世良 亘(神户商船大学)：実験条件を波高により整 理していますが、波周期、波と船との出会い周期 が変化すれば、摇れの状態は、変化すると考えら れます。他の条件とその影響について教えて下さ W。

内藤晴嗣：ご質問ありがとうございます。シミュ レータの船体横摇れ映像は、自船針路000度で航走 中、右舷正横090度から波高により波周期を制御し た横波を受ける状況で模擬しております。そして、 本実験は自船のRolling周期を一定とするように した状態で行いました。

久保雅義（神户商船大学）：波高0メートルの時の動 摇の意味は何でしょうか。

内藤晴嗣：ご質問ありがとうございます。波高 0 メートル時の動摇については、被験者が、横傾斜 の無い状態における映像を見たときの重心動摇と 考えています。そして、その值を各被験者がもつ 重心動摇の基準値として取扱っています。 